\title{
Literary Testimonials to Banal Evil. Desubjectivisation in The Narrative of Arthur Gordon Pym
}

\author{
Daniela Carstea \\ University of Bucharest/ English Department
}

\begin{abstract}
This paper attempts to construe Edgar Allan Poe to have been "the prophet of the time of dehumanisation", the prophet of Auschwitz. I'll be firstly outlining the problematics of testimony and the adjacent one, that of (banal) evil, while showing how Poe's tale reveals itself as (unwittingly) set on bringing to light obscured horrors, thus evoking similarities with the objectives of testimonials to psychic trauma. And I will supplement the philosophical response to the question of (banal) evil provided by Pia Lara, Hannah Arendt and Giorgio Agamben with a psychoanalytical one, with a footing in the signature terminology of Melanie Klein.
\end{abstract}

Keywords: inscription; mechanics of trauma; non-subject; serial splitting; total violence. 